\title{
Races of Puccinia graminis in the United States During 1996
}

\author{
D. V. McVey, Research Plant Pathologist, and D. L. Long, Plant Pathologist, Cereal Disease Laboratory, Agricul- \\ tural Research Service, USDA, University of Minnesota, St. Paul 55108; and J. J. Roberts, Retired, Research Plant \\ Pathologist, Cereal Rust Research, Agricultural Research Service, USDA, Georgia Agricultural Experiment Station, \\ Experiment 30212
}

\begin{abstract}
McVey, D. V., Long, D. L., and Roberts, J. J. 1999. Races of Puccinia graminis in the United States during 1996. Plant Dis. 83:871-875.

Stem rust caused negligible yield losses in 1996 in the United States. Wheat stem rust was first found during the second week of April in a field of soft red winter wheat southwest of Houston, Texas. Race Pgt-TPMK continues to predominate, with $66 \%$ of 273 isolates from 100 collections. TPMK represented 76 and $63 \%$ of the isolates from wheat in fields and nurseries, respectively. Race QFCS was identified at a frequency of 12 and $29 \%$ from farm fields and nurseries, respectively, and $26 \%$ overall. Eight other races consisted of $3 \%$ or less of the isolates. From barley, race QCCJ, virulent to the Rpg-1 gene for resistance to stem rust, was identified in only $12 \%$ of 77 isolates of 27 collections, while TPMK consisted of $64 \%$ of the isolates. No virulence was found to wheat lines with genes $\operatorname{Sr} 9 \mathrm{~b}, 13,22,24,25,26,27,29,30,31,32,37, \mathrm{Gt}$, or Wld-1. Oat stem rust was first found in late April in southern Louisiana and central Texas. Race NA-27, virulent to $P g-1,-2,-3,-4$, and -8 , was again the predominant race in the United States, comprising $91 \%$ of 93 isolates from 36 collections. NA-5 and NA-16 were the other two races identified, comprising $4 \%$ each.
\end{abstract}

Puccinia graminis has been a major pathogen of small grains worldwide. In the United States, stem rust epidemics were frequent before 1940. The virtual elimination of susceptible Berberis vulgaris from the cereal producing areas of the northern Great Plains reduced the frequency of epidemics and resulted in declining numbers of races identified in the United States (6). Resistant wheat cultivars (Triticum aestivum) possessing combinations of genes of Sr2, 6, 9a, 10, 11, 17, 24, 31, and Wld have provided good protection against the reduced number of races since 1954. No major losses from stem rust have occurred in the United States in spring wheat since the mid-1950s or in winter wheat since the mid-1960s (5; D. L. Long, unpublished). However, the Puccinia graminis f. sp. tritici race Pgt-QCCJ, which first appeared in the Great Plains in 1989, was regarded

Corresponding author: D. V. McVey

E-mail: donm@puccini.crl.umn.edu

Paper No. 991220053, Scientific Journal Series, Minnesota Agricultural Experiment Station.

Accepted for publication 2 June 1999.

Publication no. D-1999-0701-010

This article is in the public domain and not copyrightable. It may be freely reprinted with customary crediting of the source. The American Phytopathological Society, 1999. as a threat to the barley crop in Minnesota, Manitoba, and the Red River Valley of North Dakota $(12,13)$. There have been no major losses to oat stem rust since 1975 (5; D. L. Long, unpublished). The majority of the oat cultivars (Avena sativa) grown in the United States are susceptible to race NA-27, the most common race of Puccinia graminis $\mathrm{f}$. $\mathrm{sp}$. avenae (1). The trend in recent years is for a single race to make up most of the pathogen population (9).

When changes in race frequency are recorded, as in the new QCCJ in the early 1990 s, the threat of the new race is evaluated, and if necessary, a search for new sources of resistance to the new race is initiated. This research is part of the continuing effort to monitor changes in race combinations present in $P$. graminis in an effort to maintain rust-resistant cultivars in North America.

\section{MATERIALS AND METHODS}

Surveys were made over a 22,000-km route covering the Great Plains, Ohio River Valley, and Gulf Coast of the United States. The surveys followed a preselected route through areas where small grain cereals are important and rust has historically been a problem. In 1996, field surveys of small grain cereals were made in the following areas: southern and central Georgia (late March through May); eastern and southern Texas (early April); northern Texas and south-central Oklahoma (late
April); southeastern Gulf Coast (mid-April to early May); southeastern states (early May); Oklahoma and Kansas (mid-May); the Ohio River Valley (early June); northwestern Kansas, Nebraska, western Iowa, South Dakota, and southern Minnesota (mid-June); and Minnesota, North Dakota, and Montana (early July and again in late July). Visual inspections for the presence of rust, using the modified Cobb scale (4), were made at commercial fields ( 4 to 50 ha) every $32 \mathrm{~km}$, or in the first field thereafter. Additional inspections were made at experimental nurseries, demonstration plots, and trap plots containing susceptible wheat, oats, barley, and rye along the route. Techniques used in the surveys and approaches for interpreting results have been described $(7,8,11)$. Whenever rust was observed in a field or nursery, leaves or stems bearing rust uredinia from a single cultivar or field were collected. Additional collections were furnished by cooperators.

A portion of each collection was used to inoculate 7-day-old seedlings of a susceptible cultivar (when the rust forma specialis was known) or a group of potentially susceptible host species (if the forma specialis was unknown). Spores suspended in lightweight mineral oil (Soltrol 170) were sprayed on plants, which were then placed in a dew chamber overnight at $18^{\circ} \mathrm{C}$. The inoculated plants had been treated with maleic hydrazide to enhance spore production (17). Following $14 \mathrm{~h}$ of darkness, very high output (VHO) fluorescent light was provided for 3 to $4 \mathrm{~h}$ while the temperature gradually rose to $25^{\circ} \mathrm{C}$ to enhance fungal penetration. Plants were then placed in a greenhouse at 18 to $28^{\circ} \mathrm{C}$, where each culture was maintained in a separate clear plastic chamber. After 12 to 14 days, up to four host plants, each bearing one uredinium or pruned to bear one uredinium, were saved. These plants were reincubated (free water, $18^{\circ} \mathrm{C}, 3$-h minimum) to eliminate surface contaminants by inducing free urediniospores to germinate and killing them by drying before infection could occur. About 4 days later, cyclone collectors were used to collect urediniospores from three uredinia into separate 00 gelatin capsules (each considered an isolate). One uredinium provided sufficient spores to inoculate a differential host series. 
The second collection of spores was made from each uredinium and bulked with those from other collections made in the same area and at the same time. The bulked spores were inoculated onto the "universally" resistant host series.

P. graminis f. sp. tritici. The differential host series consisted of wheat lines with single resistance genes $\mathrm{Sr} 5$ (CI 14159), 6 (CI 14163), $7 b$ (CI 14165), $8 a$ (CI 14167), $9 b$ (CI 17386), $9 e$ (Vernstine), $9 g$ (CnsSr9g), 11 (CI 14171), 17 (Combination VII sel.), 21 (T. monococcum), 30 (CI 330957), and 36 (CI 17385). Races were assigned using the International Pgtcode (16). An additional differential set, consisting of lines $\operatorname{Sr} 9 a$ (CI 14169), 9d (CI 14177), 10 (CI 17388), and Tmp (CI 13679), was added. The "universally" resistant wheat series consisted of host lines with resistance genes $\operatorname{Srl3}$ (CI 17387), 22 (CI 2433), 24 (CI 17474), 25 (CI 17473), 26 (PI 365582), 27 (CI 14134), 29 (CI 193108), 31 (Line E/Kavkaz), 32 (ER155), 33 (Tetra Canthatch/Ae. squarrosa), 37 (W2691/SrTt-2), Gt (Baart SrGtGt), and Wld-1(Baart/Waldron) and the cultivars Era (CI 13986), Cando (CI 17483), and Ward (CI 15892), which were selected over a period of years as resistant to stem
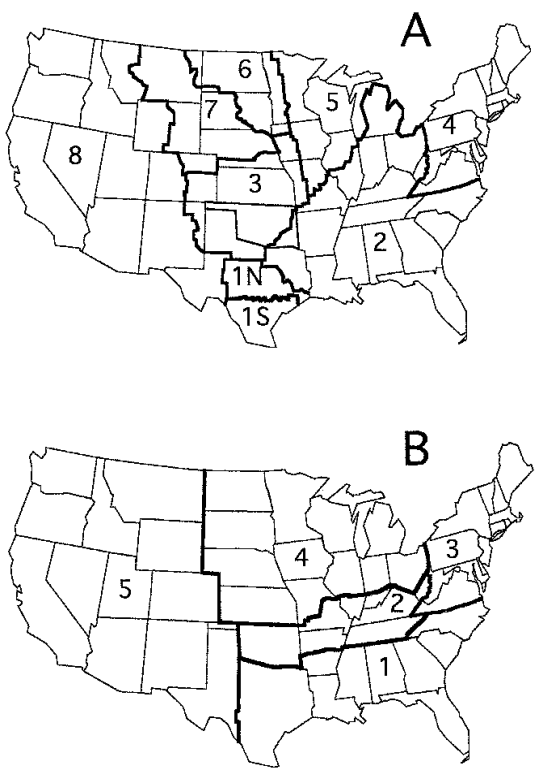

Fig. 1. Agroecological areas for Puccinia graminis in the United States. (A) Areas of wheat stem rust: $1 \mathrm{~S}$, fall seeded facultative and spring wheats, overwintering foci; $1 \mathrm{~N}$, mixed winter wheat types, rare overwintering uredinia; 2, soft red winter wheat, scattered overwintering foci; 3 , southern hard red winter; 4, mostly soft red winter wheat and barberry; 5 , isolated fields of mixed wheat types and barberry; 6 , hard red spring and durum wheat; 7 , northern hard red winter; and 8 , mostly soft winter wheat, spring wheat, and barberry. (B) Areas of oat stem rust: 1, winter oats, occasional uredinia; 2, mixed winter and spring oats, rare overwintering uredinia; 3 , spring oats and barberry; 4, spring oats and barberry; and 5 , isolated oat fields, overwintering uredinia in southern California. rust (13). Data were grouped by ecological areas of the United States (Fig. 1A) based on cultural practices, geographic separation, and wheat production.

$P$. graminis f. sp. avenae. The differential host series for identifying races of $P$. graminis f. sp. avenae consisted of oat lines with the single resistance genes $P g 1$ (CI 9318), 2 (CI9319), 3 (CI 9320), 4 (CI 6661), 8 (CI 9321), 9 (CI 9322), 13 (CI 9212), 15 (CI 9351), 16 (CI 822), and $a$ (CI 9139). Races were assigned using the NA race nomenclature (1). The "universally" resistant oat series consisted of the host lines Saia (CI 7010), CI 7221, S.E.S. No. 52 (CI 3034), X-1588-2 (CI 8457), Kyto (CI 8250), MN 730358, and CI 9139, which were selected over a period of years as resistant to stem rust (12). Data were grouped by ecological areas (Fig. 1B) based on oat production, cultural practices, and geographic separation.

\section{RESULTS AND DISCUSSION}

$P$. graminis f. sp. tritici. The first wheat stem rust was found during the second week of April in a soft red winter wheat field $97 \mathrm{~km}$ southwest of Houston, Texas. In late April, stem rust was observed in wheat at the soft dough growth stage in nursery plots in Beaumont and Beeville, Texas. By the end of April, trace amounts were found in central Texas. In early May, 2 to $5 \%$ severities were observed in two fields in southern Louisiana. Stem rust foci were found in early June in southeastern and central Kansas, and traces were found in plots and a field in east-central Arkansas. During the second week of June, an overwintering center was found in a plot of soft red winter wheat at Carbondale, Illinois, and trace severities were found in fields of soft red winter wheat in southern Illinois, throughout Indiana, and hard red winter wheat in central and northeastern Kansas. By late June, trace to $40 \%$ stem rust severities were found in plots, and traces were found in fields in northern Kansas and southern Nebraska. Hot dry weather limited further rust development in the central Plains. In early July, trace severities were widespread in Michigan, and light to moderate severities were present in south-central and light severities in southeastern Wisconsin. By mid-July, traces were found in plots at Pullman, Washington, and in trap plots (cv. Baart) in west-central Minnesota, eastern South Dakota, central North Dakota, and a winter wheat plot in west-central New York.

There was very little damage from stem rust in wheat in the Great Plains in 1996. Kansas and Nebraska reported only $0.1 \%$ loss (D. L. Long, unpublished), and only traces of stem rust appeared in farmer's fields of hard red spring wheat in Minnesota and North Dakota, where the predominant cultivars have resistance to all stem rust races identified in the Great Plains. Stem rust infection in the northern
Plains was relatively light, even in trap plots of the susceptible cultivar Baart, indicating there was not sufficient inoculum early enough in the northern Plains to create a severe epidemic even on susceptible wheat. Significant losses to stem rust did occur, however, in the Great Lakes states of Wisconsin, Michigan, Illinois, and Indiana, where losses range from 2 to $3 \%$ (D. L. Long, unpublished). Wheat cultivars grown in these states generally have few genes for resistance to stem rust.

Ten races of wheat stem rust were identified from 273 isolates from 100 collections in 1996 (Table 1). Races TPMK and QFCS comprised 66 and $26 \%$ of all isolates, respectively. From field collections, $76 \%$ of the isolates were race TPMK, whereas $63 \%$ of isolates from nurseries were TPMK. In 1994 and 1995, TPMK comprised $39 \%$ of the isolates. Race QFCS comprised $12 \%$ of isolates from farm field collections and $29 \%$ from nursery collections and remains relatively constant to 1994 and 1995 prevalence. The following races were identified from nursery collections only: QFBS (area 3, Fig. 1); QCCJ, RCRS, RFBJ (area 6); QCCS (areas 1 and 3); and RTCQ (area 5). Races RFBJ, RTCQ, and RTRS were not identified in the previous 4 years, and RKQQ and RTQQ, identified in 1994, were not identified in 1996. Race QCCJ constituted only $1 \%$ of the isolates from wheat in 1996 , while in 1995 it constituted $26 \%$. The decline of QCCJ can be attributed to removal of a wheat cultivar susceptible to QCCJ from production in Kansas, which served as the inoculum for barley fields in Minnesota and North Dakota. Very little barley is grown in the southern and central Plains. Race QCMS was identified from field collections only (area 3), and race RTRS was identified from field and nursery collections (area 3). The incidences of virulence to single gene lines used for race identification are shown in Table 2. Frequencies of virulence to $S r 7 b, 9 e, 11,36$, and Tmp showed very similar increase in 1996 over their frequencies in 1992 to 1995. These parallel changes are attributed mainly to the decline of race QCCJ, which is avirulent to these genes for resistance, and the rise of TPMK, which is virulent to them. A similar change occurred in frequency of virulence to $\operatorname{Sr} 8 a$, except that it involved not just race TPMK, but also QFCS, which like TPMK is virulent on Sr8a. No virulence was found to wheat lines $\operatorname{Sr} 9 b, 13,22,24,25,26,27,29,30$, 31, 32, 37, Gt, and Wld-1.

In mid-July, traces of stem rust were found in plots of barley in west-central Minnesota, in a field in south-central South Dakota, and in plots and fields in southeastern North Dakota. Four races were identified from 77 isolates from 27 collections of barley (Hordeum vulgare) in 1996 (Table 3). Race TPMK was the most common race identified on barley $(64 \%)$, fol- 
lowed by QFCS (19\%), QCCJ (12\%), and QCCS (5\%). Except for the greater frequency of QCCJ on barley, these values are similar to the frequencies of these races in collections from wheat (Table 2). This supports the conclusion that primary inoculum for stem rust in barley comes mainly from spores produced on wheat. In previous years, race QCCJ, which has virulence to gene Rpg-1 for resistance to stem rust, which all commercial barleys are assumed to possess, was the most common wheat stem rust race identified from barley. Thus, the most common bar- ley cultivars, Stander and Robust, are resistant to races TPMK, QFCS, and QCCS, which are avirulent to Rpg-1. The incidences of virulence to wheat stem rust differentials among isolates of $P$. graminis f. sp. tritici from $H$. vulgare are shown in Table 4.

Table 1. Frequency (\%) and source of identified races of Puccinia graminis f. sp. tritici in the United States from wheat by area and source of collections in 1996

\begin{tabular}{|c|c|c|c|c|c|c|c|c|c|c|c|c|c|}
\hline \multirow[b]{2}{*}{ Area $^{a}$} & \multirow[b]{2}{*}{ Source } & \multirow{2}{*}{$\begin{array}{c}\text { Collections } \\
(\text { no. })^{b}\end{array}$} & \multirow{2}{*}{$\begin{array}{c}\text { Isolates } \\
\text { (no.) }\end{array}$} & \multicolumn{10}{|c|}{ Percentage of each Pgt physiologic race } \\
\hline & & & & QCCJ & QCCS & QCMS & QFBS & QFCS & RCRS & RFBJ & RTCQ & RTRS & TPMK \\
\hline $1 \mathrm{~N}$ & Nursery & 5 & 14 & 14 & 14 & & & 7 & & & & & 64 \\
\hline $1 \mathrm{~S}$ & Field & 4 & 12 & & & & & 33 & & & & & 67 \\
\hline \multirow[t]{3}{*}{2} & Field & 2 & 3 & & & & & 33 & & & & & 67 \\
\hline & Nursery & 21 & 54 & & & & & 22 & & & & & 78 \\
\hline & Total & 23 & 57 & & & & & 23 & & & & & 77 \\
\hline \multirow[t]{3}{*}{3} & Field & 5 & 13 & & & 46 & & 8 & & & & 8 & 38 \\
\hline & Nursery & 13 & 39 & & 3 & & 3 & 26 & & & & 5 & 64 \\
\hline & Total & 18 & 52 & & 2 & 12 & 2 & 21 & & & & 6 & 58 \\
\hline \multirow[t]{3}{*}{5} & Field & 10 & 24 & & & & & 4 & & & & & 96 \\
\hline & Nursery & 4 & 10 & & & & & & & & 10 & & 90 \\
\hline & Total & 14 & 34 & & & & & 3 & & & 3 & & 94 \\
\hline \multirow[t]{3}{*}{6} & Field & 2 & 6 & & & & & & & & & & 100 \\
\hline & Nursery & 31 & 89 & 2 & 4 & & & 45 & 1 & 1 & & & 46 \\
\hline & Total & 33 & 95 & 2 & 4 & & & 42 & 1 & 1 & & & 49 \\
\hline 7 & Nursery & 3 & 9 & & & & & & & & & & 100 \\
\hline 8 & Field & 1 & 3 & & & & & 100 & & & & & \\
\hline \multirow[t]{3}{*}{ U.S. } & Field & 23 & 58 & & & 10 & & 12 & & & & 2 & 76 \\
\hline & Nursery & 77 & 215 & 2 & 3 & & $* \mathrm{~d}$ & 29 & $*$ & $*$ & $*$ & 1 & 63 \\
\hline & Total & 100 & 273 & 1 & 3 & 2 & $*$ & 26 & $*$ & $*$ & $*$ & 1 & 66 \\
\hline
\end{tabular}

a See Figure 1A. Area 8 not included in U.S. totals.

${ }^{\mathrm{b}}$ Uredinia from a single field, plant, or cultivar constituted a collection from which up to three single uredinia (isolates) were identified.

c International Pgt races (16): set four includes $\operatorname{Sr} 9 a, 9 d, 10, \mathrm{Tmp}$.

${ }^{\mathrm{d}}$ Less than $0.6 \%$.

Table 2. Incidence of virulence in isolates of Puccinia tritici f. sp. tritici from wheat toward single gene differential wheat lines in 1996 survey in the United States

\begin{tabular}{|c|c|c|c|c|c|c|c|c|c|c|c|c|c|c|c|c|c|c|}
\hline \multirow[b]{2}{*}{ Area $^{a}$} & \multirow[b]{2}{*}{ Source } & \multirow[b]{2}{*}{ Isolates } & \multicolumn{16}{|c|}{ Percentage of isolates virulent to $S r$ gene } \\
\hline & & & 5 & 6 & $7 b$ & $8 a$ & $9 a$ & $9 b$ & $9 d$ & $9 e$ & $9 g$ & 10 & 11 & 17 & 21 & 30 & 36 & Tmp \\
\hline \multirow[t]{3}{*}{ U.S. } & Field & 59 & 100 & 3 & 78 & 90 & 25 & 2 & 100 & 75 & 100 & 98 & 78 & 100 & 100 & 0 & 86 & 75 \\
\hline & Nursery & 214 & 100 & 1 & 65 & 94 & 35 & 1 & 100 & 63 & 100 & 100 & 64 & 91 & 100 & 0 & 64 & 63 \\
\hline & Total & 273 & 100 & 1 & 68 & 93 & 33 & 1 & 100 & 66 & 100 & 100 & 67 & 93 & 100 & 0 & 69 & 66 \\
\hline $1 \mathrm{~N}$ & Nursery & 14 & 100 & 0 & 64 & 71 & 21 & 0 & 100 & 64 & 100 & 100 & 64 & 100 & 100 & 0 & 64 & 64 \\
\hline $1 \mathrm{~S}$ & Field & 12 & 100 & 0 & 67 & 100 & 33 & 0 & 100 & 67 & 100 & 100 & 67 & 100 & 100 & 0 & 67 & 67 \\
\hline \multirow[t]{3}{*}{2} & Field & 3 & 100 & 0 & 67 & 100 & 33 & 0 & 100 & 67 & 100 & 100 & 67 & 100 & 100 & 0 & 67 & 67 \\
\hline & Nursery & 54 & 100 & 0 & 78 & 100 & 22 & 0 & 100 & 78 & 100 & 100 & 78 & 67 & 100 & 0 & 78 & 78 \\
\hline & Total & 57 & 100 & 0 & 77 & 100 & 23 & 0 & 100 & 77 & 100 & 100 & 77 & 68 & 100 & 0 & 77 & 77 \\
\hline \multirow[t]{3}{*}{3} & Field & 13 & 100 & 8 & 46 & 54 & 62 & 8 & 100 & 38 & 100 & 100 & 46 & 100 & 100 & 0 & 92 & 38 \\
\hline & Nursery & 39 & 100 & 5 & 69 & 97 & 36 & 5 & 100 & 64 & 100 & 100 & 69 & 97 & 100 & 0 & 69 & 64 \\
\hline & Total & 52 & 100 & 6 & 63 & 87 & 42 & 6 & 100 & 58 & 100 & 100 & 63 & 98 & 100 & 0 & 75 & 58 \\
\hline \multirow[t]{3}{*}{5} & Field & 25 & 100 & 4 & 96 & 100 & 8 & 0 & 100 & 92 & 100 & 96 & 96 & 100 & 100 & 0 & 92 & 92 \\
\hline & Nursery & 9 & 100 & 0 & 100 & 100 & 0 & 0 & 100 & 100 & 100 & 100 & 100 & 100 & 100 & 0 & 100 & 100 \\
\hline & Total & 34 & 100 & 3 & 97 & 100 & 6 & 0 & 100 & 94 & 100 & 97 & 97 & 100 & 100 & 0 & 94 & 94 \\
\hline \multirow[t]{3}{*}{6} & Field & 6 & 100 & 0 & 100 & 100 & 0 & 0 & 100 & 100 & 100 & 100 & 100 & 100 & 100 & 0 & 100 & 100 \\
\hline & Nursery & 89 & 100 & 0 & 48 & 92 & 51 & 1 & 100 & 46 & 100 & 100 & 46 & 99 & 100 & 0 & 47 & 46 \\
\hline & Total & 95 & 100 & 0 & 52 & 93 & 47 & 1 & 100 & 49 & 100 & 100 & 49 & 99 & 100 & 0 & 51 & 49 \\
\hline 7 & Nursery & 9 & 100 & 0 & 100 & 100 & 0 & 0 & 100 & 100 & 100 & 100 & 100 & 100 & 100 & 0 & 100 & 100 \\
\hline U.S. & $1995^{b}$ & & 100 & 0 & 47 & 60 & 31 & 0 & 100 & 39 & 100 & 100 & 39 & 100 & 100 & 0 & 47 & 39 \\
\hline U.S. & $1994^{c}$ & & 100 & 5 & 48 & 71 & 35 & 8 & 100 & 39 & 100 & 100 & 40 & 100 & 100 & 0 & 48 & 39 \\
\hline U.S. & $1993^{d}$ & & 100 & $* \mathrm{f}$ & 53 & 76 & 19 & $*$ & 100 & 57 & 100 & 95 & 57 & 94 & 100 & 0 & 57 & 57 \\
\hline U.S. & $1992^{\mathrm{e}}$ & & 100 & 0 & 31 & 44 & 19 & 0 & 100 & 31 & 100 & 99 & 31 & 100 & 100 & 0 & 31 & 31 \\
\hline
\end{tabular}

a See Figure 1A. Area 8 not included in U.S. totals.

${ }^{\mathrm{b}} \mathrm{McVey}$ et al. (3). Does not include Hordeum collections.

${ }^{c}$ McVey et al. (2). Does not include Hordeum collections.

${ }^{\mathrm{d}}$ Roelfs et al. (15). Includes Hordeum collections.

${ }^{\mathrm{e}}$ Roelfs et al. (14).

$\mathrm{f} *=$ less than $0.6 \%$. 
P. graminis f. sp. avenae. Trace amounts of oat stem rust were found in late April in southern Louisiana, and in a nursery in central Texas. In early May, stem rust was found at 20 to $30 \%$ stem rust severity on a susceptible cultivar in central Louisiana, and $30 \%$ severities were reported on cultivated oat in the Sacramento Valley, California, where traces of stem rust also occurred on wild oat (Avena fatua). By late May, trace to $80 \%$ severities were observed in southern Louisiana nurseries. During the last week of June, oat stem rust was first detected in northern Kansas. Trace amounts were found in north-central Minnesota, southern South Dakota, and on wild oat in southern North Dakota. Race NA27 (areas 1 and 4, Fig. 1B), virulent to $P g-1,-2,-3,-4$, and -8 , continued to predominate, with $91 \%$ of 93 isolates from 36 collections. Race NA5 (area 5 only), virulent to $P g-3$ and -15 , and race NA16 (area 1), virulent to $P g-1,-3$, and -8 , each comprised $4 \%$ of the isolates in the United States. Terminal severities were light and little loss occurred. NA5, NA16, and NA27 were the main oat stem rust races identified from 1992 to 1996 (Table 5). NA5 has been found only in area 5 , where its frequency increased from $29 \%$ in 1992 to $100 \%$ in 1996 . NA5 is generally associated with wild oat in area 5. NA27, the predominant race in areas 1 and 4 , has declined in frequency in area 5. NA16 has been found in relatively low frequencies in most years in area 1 and less often in area 4. Both NA5 and NA16 are relatively simple races that lack virulence to attack common oat cultivars grown in area 4 . Oat lines with genes $P g-9,-13,-16$, and $-a$

Table 3. Frequency and source of identified races of Puccinia graminis f. sp. tritici from Hordeum vulgare in 1996 in the United States

\begin{tabular}{llcccccc}
\hline & & $\begin{array}{c}\text { Collection } \\
\text { Area }\end{array}$ & Source & Isolates & & \multicolumn{3}{c}{ Percentage of each Pgt physiologic race } \\
\cline { 8 - 9 } & (no.) & (no.) & QCCJ & QCCS & QFCS & TPMK \\
\hline 5 & Field & 1 & 3 & & & & 100 \\
& Nursery & 1 & 3 & & & & 100 \\
& Total & 2 & 6 & & & & 100 \\
6 & Field & 11 & 30 & 20 & & 7 & 73 \\
& Nursery & 14 & 41 & 7 & 10 & 32 & 51 \\
& Total & 25 & 71 & 13 & 6 & 21 & 61 \\
8 & Field & 1 & 3 & 67 & & 33 & \\
\multirow{2}{*}{ U.S. } & Field & 12 & 33 & 18 & & 6 & 76 \\
& Nursery & 15 & 44 & 7 & 9 & 30 & 55 \\
& Total & 27 & 77 & 12 & 5 & 19 & 64 \\
\hline
\end{tabular}

${ }^{\text {a }}$ See Figure 1A. Area 8 not included in U.S. totals.

${ }^{\mathrm{b}}$ Uredinia from a single field plant or cultivar constituted a collection from which up to three single uredinia (isolates) were identified.

${ }^{\mathrm{c}}$ International Pgt race (16); set four includes $\operatorname{Sr} 9 a, 9 d, 10$, Tmp. were resistant to all stem rust isolates from the United States. No virulence was detected to any of the oat lines in the resistant series. The lack of oat stem rust epidemics could be due to small numbers of overwintering uredinia, late onset of disease $(10,13)$, small acreage of oat grown, or to unfavorable environmental conditions for development of regional epidemics.

\section{ACKNOWLEDGMENTS}

We thank Mark Hughes for assistance with data analysis and David H. Casper for technical assistance with the survey.

\section{LITERATURE CITED}

1. Harder, D. E. 1994. Identification of new races of Puccinia graminis f. sp. avenae. Plant Dis. 78:367-368.

2. McVey, D. V., Long, D. L., and Roberts, J. J. 1996. Races of Puccinia graminis in the United States during 1994. Plant Dis. 80:8589.

3. McVey, D. V., Long, D. L., and Roberts, J. J. 1997. Races of Puccinia graminis in the United States during 1995. Plant Dis. 81:306310.

4. Peterson, R. F., Campbell, A. B., and Hanna, A. E. 1948. A diagrammatic scale for estimating rust intensity on leaves and stems of cereals. Can. J. Res. C. 26:496-500.

5. Roelfs, A. P. 1978. Estimated losses caused by rust in small grain cereals in the United States - 1918-1976. U.S. Dep. Agric., Agric. Res. Serv. Misc. Publ. 1363.

6. Roelfs, A. P. 1982. Effects of barberry eradication on stem rust in the United States. Plant Dis. 66:177-181.

7. Roelfs, A. P. 1985. Epidemiology in North America. Pages 403-434 in: The Cereal Rusts. Vol. II, Diseases, Distribution, Epidemiology, and Control. A. P. Roelfs and W. R. Bushnell, eds. Academic Press, Orlando, FL.

8. Roelfs, A. P. 1990. Epidemiology of the cereal rusts in North America. Can. J. Plant Pathol. 11:86-90.

Table 4. Frequency (\%) of virulence among isolates of Puccinia graminis f. sp. tritici from Hordeum vulgare toward single gene differential wheat lines in the 1996 survey in the United States

\begin{tabular}{|c|c|c|c|c|c|c|c|c|c|c|c|c|c|c|c|c|c|c|}
\hline \multirow[b]{2}{*}{ Area $^{\mathbf{a}}$} & \multirow[b]{2}{*}{ Source } & \multirow[b]{2}{*}{ Isolates } & \multicolumn{16}{|c|}{ Percentage of isolates virulent to $S r$ genes } \\
\hline & & & 5 & 6 & $7 b$ & $8 a$ & $9 a$ & $9 b$ & $9 d$ & $9 e$ & $9 g$ & 10 & 11 & 17 & 21 & 30 & 36 & Tmp \\
\hline \multirow[t]{3}{*}{5} & Field & 3 & 100 & 0 & 100 & 100 & 0 & 0 & 100 & 100 & 100 & 100 & 100 & 100 & 100 & 0 & 100 & 100 \\
\hline & Nursery & 3 & 100 & 0 & 100 & 100 & 0 & 0 & 100 & 100 & 100 & 100 & 100 & 100 & 100 & 0 & 100 & 100 \\
\hline & Total & 6 & 100 & 0 & 100 & 100 & 0 & 0 & 100 & 100 & 100 & 100 & 100 & 100 & 100 & 0 & 100 & 100 \\
\hline \multirow[t]{3}{*}{6} & Field & 30 & 100 & 0 & 73 & 80 & 7 & 0 & 100 & 73 & 100 & 100 & 73 & 100 & 100 & 0 & 73 & 73 \\
\hline & Nursery & 41 & 100 & 0 & 51 & 83 & 41 & 0 & 100 & 51 & 100 & 100 & 51 & 100 & 100 & 0 & 51 & 51 \\
\hline & Total & 71 & 100 & 0 & 61 & 82 & 27 & 0 & 100 & 61 & 100 & 100 & 61 & 100 & 100 & 0 & 61 & 61 \\
\hline 8 & Field & 3 & 100 & 0 & 0 & 33 & 33 & 0 & 100 & 0 & 100 & 100 & 0 & 100 & 100 & 0 & 0 & 0 \\
\hline \multirow[t]{3}{*}{ US } & Field & 33 & 100 & 0 & 76 & 82 & 6 & 0 & 100 & 76 & 100 & 100 & 76 & 100 & 100 & 0 & 76 & 76 \\
\hline & Nursery & 44 & 100 & 0 & 55 & 84 & 39 & 0 & 100 & 55 & 100 & 100 & 55 & 100 & 100 & 0 & 55 & 55 \\
\hline & Total & 77 & 100 & 0 & 64 & 83 & 25 & 0 & 100 & 64 & 100 & 100 & 64 & 100 & 100 & 0 & 64 & 64 \\
\hline
\end{tabular}

${ }^{a}$ See Figure 1A. Area 8 not included in U.S. totals.

Table 5. Frequency (\%) of races NA5, NA16, and NA17 of Puccinia graminis f. sp. avenae in areas 1, 4, and 5 from 1992 to 1996 in the United States

\begin{tabular}{|c|c|c|c|c|c|c|c|c|c|}
\hline \multirow[b]{2}{*}{ Year } & \multicolumn{3}{|c|}{ Area 1} & \multicolumn{3}{|c|}{ Area 4} & \multicolumn{3}{|c|}{ Area 5} \\
\hline & NA5 & NA16 & NA27 & NA5 & NA16 & NA27 & NA5 & NA16 & NA27 \\
\hline $1992^{a}$ & 0 & 16 & 81 & 0 & 3 & 97 & 29 & 0 & 71 \\
\hline 1993 & 0 & 0 & 100 & 0 & 0 & 100 & 44 & $0^{\mathrm{b}}$ & 0 \\
\hline 1994 & 0 & 22 & 78 & 0 & 0 & 100 & 50 & 0 & 50 \\
\hline 1995 & 0 & 16 & 84 & 0 & 11 & 89 & 100 & 0 & 0 \\
\hline 1996 & 0 & 11 & 89 & 0 & 0 & 100 & 100 & 0 & 0 \\
\hline
\end{tabular}

a NA23 (virulence 1,2,3,8) account for 3\% of the collections in area 1 in 1992.

${ }^{\mathrm{b}} \mathrm{NA} 10$ (virulence 2,3,15) was found in 56\% of collections in area 5 in 1993. 
9. Roelfs, A. P., and Groth, J. V. 1980. A comparison of virulence phenotypes in wheat stem rust populations reproducing sexually and asexually. Phytopathology 70:855-862.

10. Roelfs, A. P., and Long, D. L. 1980. Analysis of recent oat stem rust epidemics. Phytopathology 70:436-440.

11. Roelfs, A. P., and Long, D. L. 1987. Puccinia graminis development in North America during 1986. Plant Dis. 71:1089-1093.

12. Roelfs, A. P., Long, D. L., and Roberts, J. J. 1993. Races of Puccinia graminis in the
United States during 1990. Plant Dis. 77:125128.

13. Roelfs, A. P., Long, D. L., and Roberts, J. J. 1993. Races of Puccinia graminis in the United States during 1991. Plant Dis. 77:129132.

14. Roelfs, A. P., Long, D. L., and Roberts, J. J. 1993. Races of Puccinia graminis in the United States during 1992. Plant Dis. 77:1122-1125.

15. Roelfs, A. P., Long, D. L., and Roberts, J. J. 1995. Races of Puccinia graminis in the
United States during 1993. Plant Dis. 79:969 972.

16. Roelfs, A. P., and Martens, J. W. 1988. An international system of nomenclature for Puccinia graminis f. sp. tritici. Phytopathology 78:526-533.

17. Rowell, J. B. 1984. Controlled infection by Puccinia graminis f. sp. tritici. Pages 291-332 in: The Cereal Rusts. Vol. I, Origins, Specificity, Structure, and Physiology. W. R. Bushnell and A. P. Roelfs, eds. Academic Press, Orlando, FL. 